Уипурене Айсте Барбора

д-р пед. наук, преподаватель, лектор

Мартинайтис Миндаугас

магистрант

Литовский университет спорта

г. Каунас, Литовская Республика

DOI $10.21661 / r-530727$

\title{
PECULIARITIES OF DANCERS TRAINING
}

Аннотация: чтобы танцуоры выглядели наиболее эффектно, им необходимо двигаться как единое тело, поддерживая плавное движение под музыку, несмотря на смену направления. В движение нужно вкладывать больше силь, чем обычно, при этом сохраняя пластичность ног и ровную осанку. Малейшие ошибки, обусловленные утомлением, могут стать ключевым фактором в решении о прохождении танцоров в следующчй раунд. Цель исследования - изучить литературу и выявить особенности подготовки танизоров латиноамериканской программьл.

Ключевые слова: латиноамериканские таниьы, физическая подготовка, баланс.

Abstract: for dancers to look mostly effective, they need to move as a single body, maintaining a smooth movement along with the music, despite changing directions. Each movement should be more amplified than usual, but with gentle footwork and elegant posture. The slightest deficiency in some ability due to fatigue is a determining factor in whether the dancers will enter the next round. Research aim is to analyze the literature and to reveal Latin American dancers training peculiarities.

Keywords: Latin American dances, physical fitness, balance.

\section{Introduction}

Dance sport consists of many synchronous movements of the body performed rhythmically according to the music. Dance allows people to have a beautiful posture and the ability to improve their motor abilities (Bastug, 2018). Dance sport is similar 
to the gymnastics exercise and is characterized by similar moving abilities such as aerobic and anaerobic endurance, balance, flexibility, agility, muscle strength and quickness (Kassing \& Jay, 2003). For dancers to look mostly effective, they need to move as a single body, maintaining a smooth movement along with the music, despite changing directions. Each movement should be more amplified than usual, but with gentle footwork and elegant posture. The slightest deficiency in some ability due to fatigue is a determining factor in whether the dancers will enter the next round.

Research aim - to analyze the literature and to reveal Latin American dancers training peculiarities.

\section{Results and Conclusions}

Literature analysis has shown that elite dancers male and female maximal oxygen uptake $\left(\mathrm{VO}_{2}\right)$ increases to $-59.26 \mathrm{ml} \cdot \mathrm{kg}^{-1} \cdot \mathrm{min}^{-1}$ ir $46.35 \mathrm{ml} \cdot \mathrm{kg}^{-1} \cdot \mathrm{min}^{-1}$ (Bria et al., 2011; Klonova et al., 2011). The highest average lactate level for male and female dancers after competition: 9.6 ir $8.9 \mathrm{mmol} / \mathrm{l}$ (Klonova et al., 2011). These data showed that male and female sports dancers have a relatively higher aerobic and anaerobic load compared to other dance styles such as ballet (Oreb et al., 2006). The aerobic capacity of international level dancers is quite high compared to other dance styles (ballet, contemporary dance, flamenco and folk dance) (Liiv et al., 2014) thus, it can be stated that dancers should have trainings with simulated competitive activities, during which they must dance at full tempo as if they were simulating competitive activities.

When the dancers reach the open class, they already have the ability to perform combinations that include not only classical figures but also many more complex figures. Dances in an open class allows for a wide variety of movements that require greater flexibility. Flexibility is one of the basic motor abilities which helps to perform movements in different amplitudes. Balance is a reflex of the central nervous system, which means that the body's movement system performs tasks in static and dynamic harmony. The system that balances, determines the position and direction of the body in space, decides whether the body should be dynamic or static (Bastug, 2018). 
In conclusion, most dancers show only their technical skills in dancing competitions, which is often boring to the referee, and as a result they score lower. It's happening because the dancers have not worked on their dance technique at home enough and are trying to replicate everything instead of trying to create a good emotional state for the audience. Having a better balance, the dancer has the opportunity to relax more when dance in the competition. Relaxation during the competition helps you to concentrate on dancing musically with your partner. When the dancers are able to look relaxed, the clear image is that they know what they are doing and this gives the judges a great reason to judge better.

\section{Список литературы}

1. Bastug G. Examination of Body Composition, Flexibility, Balance, and Concentration Related to Dance Exercise // Asian Journal of Education and Training. 2018 - Vol. 3. - P. 210-215.

2. Bria S. Physiological characteristics of elite sport-dancers / S. Bria, M. Bianco, C. Galvani [et al.] // The journal of sports medicine and physical fitness. - 2011. Vol. 2. - P. 194-203.

3. Kassing G. Dance teaching methods and curriculum design / G. Kassing, D.M. Jay // Human Kinetics. - 2003.

4. Kḷonova A. Smart motion capture system measuring movements of professional standard sports dancers in promenade position / A. Klonova, J. Klonovs, A. Giovanardi [et al.] // LASE Journal of Sport Science. - 2011. - Vol. 2. - P. 26-32.

5. Liiv H. Physiological characteristics of elite dancers of different dance styles / H. Liiv, T. Jürimäe, J. Mäestu [et al.] // European Journal of Sport Science. - 2014. Vol. 14. - P. 429-436.

6. Oreb G. Physical fitness, menstrual cycle disorders and smoking habit in Croatian National Ballet and National Folk Dance Ensembles / G. Oreb, L. Ružić, B. Matković // Collegium antropologicum. - 2006. - Vol. 30. - P. 279-283. 